\title{
The role of adipokines in systemic sclerosis: a missing link?
}

\author{
Jakub Żółkiewicz ${ }^{1}$ (D) . Anna Stochmal ${ }^{1}$ (D) - Lidia Rudnicka' ${ }^{1}$ (])
}

Received: 14 July 2018 / Revised: 27 December 2018 / Accepted: 12 February 2019 / Published online: 26 February 2019

(c) The Author(s) 2019

\begin{abstract}
Systemic sclerosis is a multiorgan autoimmune disease characterized by vasculopathy and tissue fibrosis of unknown etiology. Recently, adipokines (cell signaling proteins secreted by adipose tissue) have attracted much attention as a cytokine family contributing to the various pathological processes of systemic sclerosis. Adipokines, such as leptin, adiponectin, resistin, adipsin, visfatin or chemerin are a heterogenic group of molecules. Adiponectin exhibits anti-fibrotic features and affects inflammatory reactions. Leptin promotes fibrosis and inflammation. Resistin was linked to vascular involvement in systemic sclerosis. Visfatin was associated with regression of skin lesions in late-stage systemic sclerosis. Chemerin appears as a marker of increased risk of impaired renal function and development of skin sclerosis in the early stage of systemic sclerosis. Vaspin was indicated to have a protective role in digital ulcers development. Novel adipokines—adipsin, apelin, omentin and CTRP-3 - are emerging as molecules potentially involved in SSc pathogenesis. Serum adipokine levels may be used as predictive and diagnostic factors in systemic sclerosis. However, further investigations are required to establish firm correlations between distinct adipokines and systemic sclerosis.
\end{abstract}

Keywords Adipokines · Adiponectin · Resistin · Leptin · Visfatin · Chemerin · Pathogenesis · Systemic sclerosis · Vaspin · Adipsin · Apelin · Omentin · CTRP-3

\section{Introduction}

Systemic sclerosis ( $\mathrm{SSc}$ ) is an autoimmune connective tissue disease. It is characterized by a chronic course, significantly affecting length and quality of life $[55,56]$. The hallmarks of SSc are progressive skin thickening and visceral fibrosis associated with atrophy of subcutaneous tissue, vascular involvement as well as immune dysregulation [58]. The pathogenesis of SSc is still not clearly understood. Genetic, vascular, autoimmune and environmental factors are postulated to have an impact on SSc development [115].

Adipose tissue is believed to be one of the largest endocrine organs in humans [53]. Adipocytes are metabolically active cells and their products are called adipokines. Adipokines are a non-homogenous group of proteins, which can be subdivided, according to their mechanism of action, into auto-, para- and endocrine hormones [52]. The group of adipokines includes: adiponectin, resistin, leptin, visfatin,

Lidia Rudnicka

lidia.rudnicka@dermatolodzy.com.pl

1 Department of Dermatology, Medical University of Warsaw, Koszykowa 82A, 02-008 Warszawa, Poland chemerin, vaspin and many more, including cytokines (IL-6, TNF- $\alpha$ ), coagulation factors (PAI-1), growth factors (VEGF, TGF- $\beta$ ) or complement system proteins (adipsin) [4]. Adipokines play a vital role in homeostasis and every disharmony in this precise system may contribute to the development of various diseases such as hypertension or type 2 diabetes [30]. However, the link between adipokines and SSc is still discussed. The aim of this review is to analyze and summarize current data related to the role of adipokines in the pathogenesis of SSc, future perspectives and potential directions for investigations.

\section{Adipose tissue in systemic sclerosis}

Adipose tissue seems to play a crucial role in skin homeostasis and remodeling [101]. Furthermore, degradation of intradermal adipose tissue precedes the onset of dermal fibrosis [74]. Positive feedback loop is suspected wherein adipose tissue is a source of factors exacerbating fibrosis and its replacement by fibroblasts enhances collagen fibers production. 


\section{Adipose tissue and immune system}

Adipose tissue stays in a close relationship with the immune system. Adipokines are considered to modulate immune response and interdependence between both systems has been reported to date [34]. Adipokines affect activation and attraction of many immune cells which results in accumulation and differentiation of $\mathrm{CD}^{+}, \mathrm{CD} 8^{+}$lymphocytes $\mathrm{T}$ as well as Th17 cells [108]. It appears that both Th1 and Th2 are involved in SSc pathogenesis, although each population dominates in a different stage of the disease: Th2 cells in early stage and Th1 cells later in the course of SSc [43]. Both Th1 and Th2 induce inflammatory reaction, but exacerbated fibrosis occurs when prevalence of Th2 cells and production of IL-4, IL-5 and IL-13 occurs (as a direct mechanism of collagen synthesis augmentation). Th1 lymphocytes attenuate collagen production and cause collagen degradation [123].

The number of Th17 cells and their most prominent product IL-17 are elevated in patients with SSc [130]. IL-17 retains pro-fibrotic state of various cells, impacts differentiation of fibroblasts, inhibits autophagy and exacerbates overall inflammatory status, implicating its role in the pathogenesis of SSc [54, 64, 114, 121]. Adipokines are strongly linked with Th17 cells differentiation. Adiponectin, which is protective in SSc, suppresses Th17 cells differentiation [133]. On the contrary, leptin and resistinlike molecule $\alpha$ (RELM- $\alpha)$ have the ability to promote pathogenic Th17 cell response [90, 100].

Macrophages can be divided into M1 and M2 subtypes. M1 macrophages stimulate inflammatory processes mostly by IL- 1 , IL- 6 , IL- 12 and TNF- $\alpha$, while M2 macrophages after stimulation via IL-4, IL-10, IL-13 decrease inflammation and promote tissue repair [78]. Adipokines have an impact on the proliferation of both M1 and M2 population, thus contributing in the course of the disease.

\section{Adipocyte-myofibroblast transition and epithelial- mesenchymal transition}

Fibrous tissue in SSc is a product of myofibroblasts. However, the source of myofibroblasts in the skin of patients with SSc is still discussed. One theory suggests that myofibroblasts are derived from pericytes released from damaged vessels [99]. Another, that myofibroblasts originate from adipocytes which undergo adipocyte-myofibroblast transition (AMT) [74]. The reason of adipose tissue loss is not only apoptosis, thus AMT process may be an explanation for adipocytes depletion in SSc [122]. This thesis stays in conformity with histological images of skin lesions in $\mathrm{SSc}$, in which increase of myofibroblasts amount is at the expense of adipose tissue loss [29]. There are many similarities between AMT and epithelial-mesenchymal transition (EMT), which is a process whereby cells acquire mesenchymal features, loose intercellular contact and gain ability to migrate [135]. Partial EMT-like changes may contribute to fibrosis in the skin of patients with SSc [86]. Interestingly, differentiation of fibroblasts into myofibroblasts is a reversible process, giving a potential possibility to invert it and find new drugs attenuating fibrosis [129]. It was proved that many adipokines, especially visfatin and progranuline are involved in the process of EMT, which is a transition akin to AMT process [21, 128].

\section{PPARs and TLRs-main receptors involved in regulation of adipokines synthesis}

Peroxisome proliferator-activated receptors (PPARs) are nuclear receptors which regulate gene expression by binding to DNA structure. A pleiotropic effect of their activation involves whole body homeostasis and metabolism [60]. The family of these consists of three subtypes, PPAR- $\alpha$, PPAR- $\beta$ and PPAR- $\gamma$. All subtypes of PPAR receptors are expressed in adipocytes, but PPAR- $\gamma$ is believed to be crucial in inducing adipocyte differentiation and synthesis of adipokines [109]. PPARs agonists increase anti-inflammatory and lower pro-inflammatory levels of adipokines; in adipocytes, ligand activation of PPAR- $\gamma$ was associated with increased production of adiponectin and decreased production of resistin and leptin [65]. It was indicated that PPAR- $\gamma$ stimulation in nonadipocyte cells leads to an increased concentration of adiponectin and visfatin, while synthesis of resistin is decreased [82, 93, 122]. Adipokines also affect PPARs backward, what might be considered as a feedback loop mechanism-leptin has been proved to lower expression of PPAR- $\gamma$ receptors in macrophages [16]. An experimental therapy with PPARs agonist was shown to attenuate fibrosis and this fact makes PPARs a promising therapeutic target in SSc [9].

Toll-like receptors (TLRs) recognize both exogenous (fragments of pathogens) and endogenous (products derived from injured tissues) ligands [19]. Ten members of TLR family TLR 1-10 can be distinguished. TLR4 expression is dominating in adipose tissue, however, the presence of TLR1, TLR4, TLR7 and TLR8 was also reported. TLRs localized on adipocytes are capable of influencing the course of SSc due to stimulation of inflammation via molecular pathways activating NF- $\mathrm{KB}$ transcription factor and modulation of immune response [117]. TLRs agonists may induce endotheline 1 (ET-1) upregulation [27], which was reported to implicate in the vascular complications and fibrosis in SSc. TLR4 activation in particular is postulated to result in persistent fibrosis [13]. That fact may open new possibilities of targeted therapy in SSc (Fig. 1). 


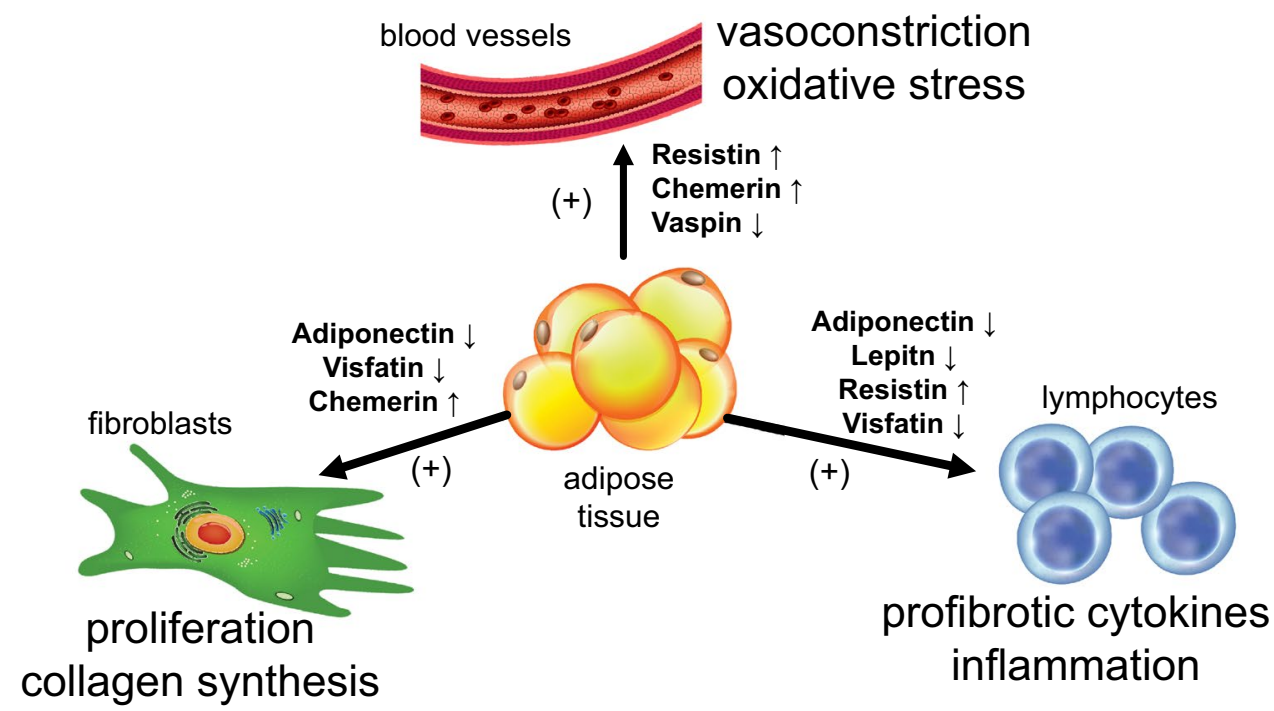

Fig. 1 The role of adipokines in the active phase of systemic sclerosis and their effect on immune cells, fibroblasts and blood vessels. The main source of adipokines is the adipose tissue. Adipokines have a pleiotropic effect on cells involved in the pathogenesis of systemic sclerosis. Elevated serum level of resistin and chemerin as well as a decreased level of vaspin result in vasoconstriction and oxidative

It was indicated that low adiponectin level in SSc patients resulted in raised macrophage M1 activity via TLR [127]. In addition, leptin upregulates TLR2 in monocytes and potentiates inflammation, while chemerin induces TLR4 in synovial fibroblasts [25, 48]. Some adipokines, like resistin, may also act as TLR agonist [12].

\section{Adipokines in systemic sclerosis}

\section{Adiponectin}

Adiponectin (APN) is a $30 \mathrm{kDa}$ hormone. The main source of APN is adipose tissue, although other cells such as endothelium, fibroblasts, leukocytes and macrophages are capable of synthesizing APN [33]. There are three main forms of APN, depending on its post-translational modification: low-molecular-weight (LMW) trimers, mediummolecular-weight (MMW) hexamers and high-molecularweight (HMW) multimers [118]. Globular adiponectin is another isoform, which is formed through the cleavage by macrophage and leukocyte elastase. It is significant in case of measuring APN level in serum, since this isoform may interfere with laboratory results due to elastase activity in skin lesions [119]. APN may induce IL-10 and IL-1 receptor antagonist (IL-1Ra) release in monocytes. It was shown that HMW and globular APN enhanced, while LMW reduced production of IL-6 [106]. Therefore, it is postulated that each of isoform acts pro- or anti-inflammatory, respectively. The stress in the endothelial cells. Increased concentration of chemerin and decreased levels of adiponectin and visfatin stimulate proliferation of fibroblasts and excessive synthesis of extracellular matrix proteins. Activation of lymphocytes and the production of pro-fibrotic cytokines are augmented as a result of decreased concentration of adiponectin, leptin and visfatin and increased concentration of resistin

measurement of total adiponectin level in serum is widely described in the literature. However, the level of each isoform may differ and might be also taken into consideration in the terms of the development of the disease, including SSc.

Metabolic syndrome and related diseases are associated with HMW, while LMW is more closely linked with autoimmune phenomena [66]. Interestingly, TNF- $\alpha$ impairs adiponectin multimerization and decreases adiponectin secretion, which may explain different ratios between APN isoforms in these disorders [40].

Two receptors for adiponectin have been distinguished, ADIPOR1 and ADIPOR2. APN polarizes macrophages into M2 subtype by ADIPOR2 stimulation which results in an increased level of pro-fibrotic interleukines [73, 87]. However, APN has also a role in polarization of CD4+ lymphocytes into Th1 and preventing from $\mathrm{Th} 2$ subtype dominance [49]. A decreased APN level was observed mostly in the early stage of SSc, resulting in a prevalence of Th2 lymphocytes and their pro-fibrotic action in this stage. In the later phase, an increased level of APN was found [59], suggesting Th1 cells and their anti-fibrotic effect domination. Apart from Th polarization mechanism, APN seems to have a direct impact on fibroblasts and fibrosis. Fibroblast-binding APNs demonstrate anti-fibrotic effect via activation kinase involved in inflammation (AMPK) [26]. In human skin biopsy, cellular phosphorylated AMPK level which reflects APN activity in fibrotic tissue was considerably decreased in SSc patients compared to healthy control [75]. Studies 
showed that APN also inhibited EMT in breast and prostate cancer, which indicates a restrain of EMT process in SSc due to increased APN level [47, 111]. Moreover, an inverse correlation between adiponectin level and the modified Rodnan skin score (mRSS) was found $[8,59]$. Adiponectin, as an anti-fibrotic molecule, may be positively correlated with disease duration and its decreased level seems to be one of the factors exacerbating fibrosis in the early stage of SSc [59].

\section{Leptin}

Leptin belongs to the type I cytokine superfamily and its structure is similar to IL-2, IL-6 and G-CSF [132]. First reports about leptin focused on its role in overweight and as a potential goal for obesity therapy [134]. In the hypothalamus, leptin suppresses appetite and plays a major role in sustaining body weight as well as energy homeostasis [103]. Serum leptin level is associated with the amount of adipose tissue in the human body [102]. Adipocytes are not the only source of leptin; it is also produced in large amounts by fibroblasts, keratinocytes and endothelial cells [96]. Highfat diet, estrogens and pro-inflammatory cytokines enhance leptin production, while catecholamines, androgens and PPAR- $\gamma$ agonists decrease its level $[38,51,102]$. Apart from the role of leptin in obesity, it is involved in developing other disorders such as type 1 diabetes, systemic lupus erythematosus and psoriasis. This may be due to affecting angiogenesis, extracellular matrix (ECM) production and enhancing inflammation [88]. Leptin acts by ObR-leptin receptor. Measurement of serum leptin receptor level may be useful in clinical practice; it was indicated that frequency of esophageal reflux was significantly lower in SSc patients with elevated than in those with reduced level of serum leptin receptor (6.3\% vs. $35.3 \%$, respectively) [88].

Moreover, an elevated serum level of leptin receptor could be a clinically useful marker of systemic sclerosis spectrum diseases (SSDs) and its measurement over time in patients with SSD may lead to early detection of SSc [88]. Although ObR is different from APN receptor, they act through the common signaling pathway. Despite similarity of signaling pathways, leptin may antagonize the activity of APN. Leptin has been associated with either acute or chronic phase of inflammation. As a cytokine, leptin affects the immune system in several ways. In murine model, leptin increased production of antinuclear antibodies [70]. Moreover, leptin polarizes Th lymphocytes into Th1 and suppress Th2 phenotype, thus enhances production of pro-inflammatory cytokines [77]. In keratinocytes, leptin increases production of IL-6, IL- 8 and TNF- $\alpha$ as well as expression of genes related to wound healing such as metalloproteinase-1 (MMP-1) [61, 126]. Furthermore, leptin enhances subtype M1 macrophage growth and differentiation [2]. Leptin activates endothelial cells and acts as a chemokine, causing attraction of macrophages into adipose tissue, hence it is involved in creating a local inflammatory niche in patients with SSc [20, 24]. The research indicated that leptin levels are significantly lower in patients with the active phase of SSc than in inactive $(1.92 \pm 2.90$ vs. $7.02 \pm 7.65 \mathrm{ng} / \mathrm{ml})$ and this fact harmonizes with the theory of Th2 lymphocytes domination in the early, active stage with enhanced fibrosis and Th1 in the latter inactive stage of SSc [15]. On the contrary, it was also shown that circulating leptin level does not significantly differ between patients with SSc and healthy controls [63]. Taking into consideration each adipokine individually may be questionable. In other diseases associated with extended fibrous tissue production, such as idiopathic pulmonary fibrosis, it was reported that measuring adiponectin/leptin ratio is useful to assess the course of the disease and helps to predict the intensity of fibrosis [72]. Except for fibrosis, low adiponectin/leptin ratio may also indicate adipose tissue dysfunction, increased oxidative stress and inflammation [32].

Apart from inducing inflammation, leptin was associated with indirect stimulation of fibrosis. Binding leptin to ObR in regulatory $\mathrm{T}$ cells (Tregs) is a signal for hyporesponsiveness and decreased proliferation of Tregs which was indicated to enhance fibrosis [22]. In addition, leptin induces human lung fibroblast to transdifferentiate into myofibroblasts responsible for collagen production [17]. Leptin promotes pulmonary fibrosis also by inhibiting autophagy via $\mathrm{PI} 3 \mathrm{~K} / \mathrm{Akt} / \mathrm{mTOR}$ pathway. Interestingly, mTOR inhibitors reversed this effect, therefore rapamycin could be considered a therapeutic agent in pulmonary fibrosis in SSc [36]. Leptin may promote fibrosis in an alternative mechanism, which involves renin-angiotensin system (RAS). In the central nervous system, leptin stimulates hypothalamic melanocortin system, increases sympathetic activity and leads to RAS activation [125]. What is more, in the elderly, leptin was associated with arterial stiffness [35], which is one of the features of vascular involvement in SSc [113]. Therefore, leptin could be used as a potential marker of vascular damage in SSc, however further investigations are required (Table 1).

\section{Resistin}

Resistin belongs to the found in inflammatory zone (FIZZ) family of proteins which means that it is overexpressed in the area of inflammation. In contrast to other adipokines, it is mainly secreted by monocytes in humans, not adipocytes [62]. Resistin is involved in human lipid, glucose and insulin homeostasis. A correlation between resistin level and obesity together with metabolic syndrome has been found. Resistin seems to be a molecular biomarker of inflammation and disorders related to metabolic syndrome such as cardiovascular disease or diabetes [1]. Due to the fact that resistin 
Table 1 Potential role of adipokines in systemic sclerosis

\begin{tabular}{|c|c|c|c|}
\hline Adipokine & Level in SSc comparing to controls & Source of sample & Correlation with complications \\
\hline Adiponectin & Decreased-only in the early stage of SSc [59] & $\begin{array}{l}\text { Serum level, } \\
\text { mRNA and skin biopsy }\end{array}$ & $\begin{array}{l}\text { Negative correlation with Valentini activity score } \\
\text { [89] and mRSS [59] }\end{array}$ \\
\hline Leptin & $\begin{array}{l}\text { Decreased (active vs. inactive SSc) [15] } \\
\text { Increased (dominating) [95] }\end{array}$ & $\begin{array}{l}\text { Serum level } \\
\text { Serum level }\end{array}$ & $\begin{array}{l}\uparrow \text { Pulmonary fibrosis [36] and pulmonary arterial } \\
\text { hypertension [46] } \\
\uparrow \text { Arterial stiffness [35] }\end{array}$ \\
\hline Resistin & Increased (no statistical significance) [95] & Serum level & $\begin{array}{l}\uparrow \text { Pulmonary arterial hypertension [79] } \\
\text { Digital ulcers biomarker [79] } \\
\text { Positive correlation with digital vasculopathy [89] } \\
\text { Chronic kidney disease biomarker [10] }\end{array}$ \\
\hline Visfatin & Increased in late stage dcSSc [80] & Serum level & $\begin{array}{l}\text { Positive correlation with regression of skin lesions } \\
\text { [80] }\end{array}$ \\
\hline Chemerin & $\begin{array}{l}\text { Increased [6] } \\
\text { Increased [5] } \\
\text { Decreased [5] }\end{array}$ & $\begin{array}{l}\text { Lesional psoriatic vs. } \\
\text { uninvolved skin } \\
\text { Dermal blood vessels } \\
\text { Dermal fibroblasts }\end{array}$ & $\begin{array}{l}\text { Positive correlation with disease duration [5] } \\
\text { Positive correlation with mRSS [5] }\end{array}$ \\
\hline Vaspin & Decreased [92] & Serum level & Biomarker of digital ulcers in SSc [84] \\
\hline Adipsin & $\begin{array}{l}\text { Increased [57] (significantly higher in lcSSc vs. } \\
\text { dcSSc) }\end{array}$ & Serum level & $\begin{array}{l}\text { Positive correlation with frequency of anti-cen- } \\
\text { tromere antibodies [57] } \\
\text { Negative correlation with frequency of anti-Scl-70 } \\
\text { antibodies [57] } \\
\text { Positive correlation with SSc-PAH [57] }\end{array}$ \\
\hline Apelin & $\begin{array}{l}\text { Decreased [131] } \\
\text { No difference [7, 131]/increased in early stage of } \\
\text { SSc vs. later stages [7] }\end{array}$ & $\begin{array}{l}\text { Fibroblasts } \\
\text { Serum level }\end{array}$ & $\begin{array}{l}\text { Negative correlation with mRSS [131] } \\
\text { Biomarker of digital ulcers }[7,131] \\
\text { Biomarker of acro-osteolysis [131] } \\
\text { Positive correlation with prevalence of scleroderma } \\
\text { renal crisis and PAH in late stage SSc [7] }\end{array}$ \\
\hline Omentin & $\begin{array}{l}\text { No difference [83] } \\
\text { Decreased in dcSSc vs. lcSSc [83] }\end{array}$ & $\begin{array}{l}\text { Serum level } \\
\text { Serum level }\end{array}$ & $\begin{array}{l}\text { Positive correlation with disease duration in dcSSc } \\
\text { [83] } \\
\text { Positive correlation with right ventricular systolic } \\
\text { pressure [83] (possible biomarker of SSc-PAH/ } \\
\text { vascular involvement) }\end{array}$ \\
\hline CTRP-3 & Not studied in SSc yet & - & - \\
\hline
\end{tabular}

is primarily secreted by macrophages, it may have a direct impact on inflammation. Despite having a significant contribution in the maintenance of energy homeostasis, resistin may exert a larger impact on inflammatory processes-resistin has been linked to rheumatoid arthritis, psoriatic arthritis and systemic lupus erythematosus and is suspected to be involved in SSc pathogenesis [89]. It is widely known that inflammation triggers fibrosis. Hence, resistin was indicated to exacerbate fibrosis. However, the meta-analysis of four studies considering resistin levels in SSc does not exhibit its significantly different level compared to healthy individuals [63].

Mechanism of pro-inflammatory action of resistin involves TLR4. Intracellular signals are mediated via NF-кB and MAPK and lead to IL-1, IL-6 and IL-8 secretion [112]. Furthermore, these pro-inflammatory cytokines increase the expression of resistin in human mononuclear cells [14]. This triggers a positive feedback loop of self-damaging process, where resistin stimulates pro-inflammatory cytokines' secretion and pro-inflammatory cytokines elevate resistin's concentration. Resistin crosses brain-blood barrier and binds to TLR4 receptors in hypothalamus resulting in systemic low-grade inflammation and insulin resistance [12]. However, the role of TLR as a link between SSc and adipokines has not been clearly established yet and requires further research.

It was proved that not only TLR4 but also PPAR- $\gamma$ is associated with the concentration of resistin in the serum. Studies showed that resistin level may be decreased by TLR4 antibodies or PPAR- $\gamma$ agonists [93, 112] providing another argument, that these molecules could be considered as potential therapeutic agents for SSc treatment.

It is worth highlighting that resistin modulates vessels activity. Vasoactive mechanism of resistin is mediated through enhancing production of ET-1 [116]. This results in vasoconstriction along with inflammatory cells attraction and diapedesis through a vessel wall. Smooth muscle cells proliferation, endothelial cells migration as well as adjacent tissue remodeling via metalloproteinases induced by resisitn [28] may additionally potentiate vasoconstriction present in 
patients with SSc [79]. Development of pulmonary arterial hypertension $(\mathrm{PAH})$ was linked to role of resistin-induced angiogenesis and immune response [79]. Furthermore, it was indicated that prevalence of digital ulcers tended to be higher in SSc patients with elevated serum resistin levels than in those with non-elevated levels (50\% vs. 16\%, respectively) [79]. Resistin stimulates P-selectin expression on human platelets, facilitating thrombus formation [98]. Moreover, the level of resistin was positively correlated with plasminogen activator inhibitor 1 (PAI-1), which is a pro-fibrotic molecule [97]. This may be one of the factors explaining higher prevalence of deep vein thrombosis and pulmonary thromboembolism in SSc patients than in general population (10.5- and 7.00-fold higher than in control group, respectively) [18].

\section{Visfatin}

Visfatin (pre-B-cell colony-enhancing factor, PBEF) is predominantly secreted by visceral adipose tissue. In human, it is correlated with metabolic disorders along with obesity. This adipokine is a PPAR- $\gamma$ depended protein and activating this molecular pathway results in inducing visfatin gene expression in macrophages, mostly M1 subtype localized in adipose tissue, but not in adipocytes [82, 124]. Effect on the immune system is confirmed by the fact that lack of visfatin expression strongly attenuated the development of both Tand B-cell lymphocytes [110]. Visfatin acts as a pro- and anti-inflammatory cytokine; it was indicated to up-regulate circulating TNF- $\alpha$, IL-1 $\beta$, IL-6 as well as IL-4, IL-10 and IL-1Ra [124]. Visfatin is also capable of increasing levels of cell adhesion molecules ICAM-1, VCAM-1 and E-selectin in endothelial cells [110]. Interestingly, pro-inflammatory activity of visfatin was abolished when insulin receptor signaling was blocked [82]. Concentration of visfatin in the serum is comparable among total SSc patients, diffuse cutaneous SSc (dcSSc), limited cutaneous SSc (lcSSc) and healthy individuals. It has been found that an increase of visfatin level in serum is accompanied by regression of skin lesions in late-stage dcSSc (>6 years duration) [80]. The proposed mechanism of this phenomenon is both visfatininduced Th1 polarisation and the direct anti-fibrotic effect on dermal fibroblast [80].

\section{Chemerin}

Chemerin is an immunomodulating protein secreted predominately by adipose tissue as well keratinocytes in basal and suprabasal layers of the skin [81]. Chemerin was associated with inflammatory processes in systemic sclerosis, rheumatoid arthritis, systemic lupus erythematosus and psoriasis. Moreover, an inverse correlation between chemerin and body mass index was found [37]. This finding suggests that production of chemerin by non-adipose tissue is independent from the amount of the body fat. Chemerin receptor (ChemR23) is localized on the surface of endothelial cells, and its expression is regulated by TNF- $\alpha$, IL- $1 \beta$ and IL-6. Signaling pathways involved in transducing signal via ChemR23 promote endothelial cell proliferation and migration, leading to endothelial barrier dysfunction [76]. Serum proteases have the ability to cleave chemerin resulting in the formation of different isoforms, which bind to macrophages and stimulate secretion of pro-inflammatory cytokines (TNF- $\alpha$, IL- 6 and IFN- $\gamma$ ). Moreover, these isoforms of chemerin seem to recruit plasmacytoid dendritic cells (pDCs) and NK cells. PDCs combat pathogens, although they may exacerbate inflammation in skin lesions and were associated with fibrosis in SSc patients [3]. Furthermore, it was shown that in other cutaneous diseases such as psoriasis, mRNA levels of chemerin were elevated in lesional skin compared to uninvolved skin of the same patients. Probable mechanism involves accumulation of chemerin which results in potentializing attraction of inflammatory cells [6].

The pro-inflammatory nature of chemerin is confirmed by the fact that adalimumab (TNF- $\alpha$ inhibitor) therapy was indicated to lower chemerin level, which was linked with reduction of rheumatoid arthritis disease activity and levels of pro-inflammatory cytokines [31].

It was indicated that serum chemerin level in patients with SSc is elevated compared to healthy individuals. However, renal dysfunction has an influence on serum concentration in both SSc patients and control group. Chemerin seems to be involved in the development of the skin sclerosis in the early stage of SSc (disease duration $<1$ year). Moreover, chemerin level was positively correlated with mRSS [5]. Association between serum chemerin level and presence of digital ulcers in SSc patients was also reported to date and may be a proof of increased chemerin expression in dermal blood vessels [5].

It is important to mention that increased chemerin level was associated with risk of impaired renal function (OR 2.72). It can be explained by direct damage of kidneys or reduced chemerin clearance in patients with SSc but also in a general population [136]. Thus, this can imply the emerging role of chemerin in internal organ disorders in SSc.

\section{Vaspin (visceral adipose tissue-derived serine protease inhibitor)}

Vaspin is an adipokine expressed predominantly in visceral adipose tissue and plays important roles in metabolic syndrome and its relevant vascular complications. Serum vaspin levels were lowered in sera of patients with SSc, however, no statistical significance was observed $(341 \pm 284$ vs. $434 \pm 343 \mathrm{pg} / \mathrm{mL}, p>0.05$ ) [92]. Despite no difference between SSc and control group, serum vaspin levels were 
Table 2 Potential mechanism of adipokines' action in SSc pathogenesis and their role in inflammation

\begin{tabular}{|c|c|c|}
\hline Adipokine & (Potential) Mechanism of action & Role in inflammation \\
\hline Adiponectin & $\begin{array}{l}\text { HMW and globular APN : } \uparrow \text { TNF- } \alpha, \text { IL-8, IL-6 }[39,106] \\
\text { LMW: } \downarrow \text { IL-6, } \uparrow \text { IL-10 [85] } \\
\text { M2 macrophage polarization [87] } \\
\uparrow \text { Th1/Th2 ratio [49] } \\
\downarrow \text { Differentiation of Th17 [133] }\end{array}$ & Anti-inflammatory (dominating) $[85,133]$ \\
\hline Leptin & $\begin{array}{l}\uparrow \text { IL-6, IL-8, TNF- } \alpha \text { [126] } \\
\uparrow \text { MMP-1 [61] } \\
\uparrow \text { Th1/Th2 ratio [77] } \\
\uparrow \text { Th17 cell response [100] } \\
\downarrow \text { Treg proliferation and activity [22] } \\
\text { Chemoattractant [20] } \\
\downarrow \text { Autophagy [36] } \\
\text { RAS activation [125] }\end{array}$ & Pro-inflammatory $[20,22,100,126]$ \\
\hline Resistin & $\begin{array}{l}\uparrow \text { IL-6, IL-8 secretion [112] } \\
\uparrow \text { ECM production (via CTGF) [50] } \\
\uparrow \text { Th17 cell response [90] } \\
\uparrow \text { ET-1 production }[116] \rightarrow \text { vasoconstriction } \\
\uparrow \text { Blood clot formation }[98]\end{array}$ & Pro-inflammatory $[90,112,116]$ \\
\hline Visfatin & $\begin{array}{l}\uparrow \text { IL-4, IL-10, IL-1Ra circulating levels [124] } \\
\uparrow \text { Development T- and B-cell lymphocyte [110] } \\
\uparrow \text { Th1/Th2 ratio [91] } \\
\uparrow \text { TNF- } \alpha, \text { IL-1 } \beta, \text { IL-6 [124] } \\
\uparrow \text { ICAM-1, VCAM-1, E-selectin, IL-6, IL-8 in endothelial cells [110] }\end{array}$ & $\begin{array}{l}\text { Anti-inflammatory (dominating) [124] } \\
\text { Pro-inflammatory [110, 124] - abolished by blocking } \\
\text { insulin receptor signaling [82] }\end{array}$ \\
\hline Chemerin & $\begin{array}{l}\text { M1 macrophage polarization [68] } \\
\uparrow \text { TNF- } \alpha \text {, IL-6, IFN- } \gamma[68] \\
\uparrow \text { PDCs, macrophages, NK cells attraction }[6,11] \\
\uparrow \text { IL-10 [68] }\end{array}$ & $\begin{array}{l}\text { Pro-inflammatory }[6,11,68] \\
\text { Anti-inflammatory }[68]\end{array}$ \\
\hline Vaspin & $\begin{array}{l}\downarrow \text { TNF- } \alpha, \text { IL-1, IL-6, ICAM-1, VCAM-1, MCP-1 [69] } \\
\downarrow \text { Leptin and resistin [42] }\end{array}$ & Anti-inflammatory $[42,69]$ \\
\hline Adipsin & Mediated via complement pathway activation [57] & Pro-inflammatory [57] \\
\hline Apelin & $\begin{array}{l}\downarrow \text { TGF- } \beta \text {-induced skin fibrosis [131] } \\
\uparrow \text { VCAM-1 and MCP-1 [71] } \\
\uparrow \text { Angiogenesis [71] } \\
\downarrow \text { TNF- } \alpha \text {, IL-1, MCP-1, MIP-1 } \alpha, \text { IL-6 [71] }\end{array}$ & $\begin{array}{l}\text { Pro-inflammatory [71] } \\
\text { Anti-inflammatory [71] } \\
\text { Pro- and anti-fibrotic in context-dependent manner [7] }\end{array}$ \\
\hline Omentin & $\begin{array}{l}\text { M2 macrophage polarization }[120] \\
\downarrow \text { ICAM-1, VCAM-1, TNF- } \alpha, \text { IL-6, MCP-1, COX-2 [120] } \\
\uparrow \text { eNOS [120] - vasodilatation } \\
\downarrow \text { Chemoattraction }[120] \\
\downarrow \text { ECM production }[120]\end{array}$ & Anti-inflammatory [120] \\
\hline CTRP-3 & $\begin{array}{l}\downarrow \text { TLRs pro-inflammatory effects [44] } \\
\downarrow \text { CTGF, TGF- } \beta \text {, collagen synthesis }[44,67] \\
\downarrow \text { Proliferation, migration of fibroblasts [67] }\end{array}$ & Anti-inflammatory [44] \\
\hline
\end{tabular}

significantly decreased in SSc patients with digital ulcers compared with those without, suggesting a protective role of vaspin to digital ulcers development [84]. Therefore, vaspin may have protective properties against endothelium dysfunction in SSc and its level may reflect endothelium condition in SSc patients. No correlation of serum vaspin levels with $\mathrm{C}$-reactive protein and erythrocyte sedimentation rate was found, which did not indicate a significant role of vaspin in the inflammatory process in SSc [84]. It can be explained by the fact that vaspin, interacting with $N F-\kappa B$ pathway was able to inhibit pro-inflammatory cytokines signaling such as TNF- $\alpha$, IL-1, IL-6 [69]. Moreover, vaspin suppresses the expression of other adipokines: leptin and resistin [41].

\section{Novel adipokines}

Adipsin (complement factor D) is a serine protease secreted by adipocytes. It has the ability to activate the alternative pathway of complement. Increased complement activity [107] and, as a result, the membrane attack complex on arterioles were observed in SSc patients [105]. Early administration of eculizumab, which is terminal complement inhibitor, manifested therapeutic potential in patients with renal crisis 
in the course of SSc [23]. Elevated serum level of adipsin in SSc was associated with vascular involvement, in particular $\mathrm{PAH}$ and is considered as a potential biomarker in this complication related to SSc [57].

Apelin is an endogenous ligand of $G$ protein-coupled receptor called APJ. It is widely expressed in central nervous system and many peripheral tissues, including adipose tissue [131]. Recent studies reported that Apelin/APJ complex alleviates renal, myocardial and lung fibrosis [45]. It was also showed that skin fibrosis induced by TGF- $\beta$ is inhibited by apelin, but precise mechanisms of this action requires further investigation [131]. Expression of apelin was significantly reduced in SSc fibroblasts compared to normal fibroblasts and serum apelin levels were negatively correlated with mRSS. However, the differences of serum apelin levels between SSc patients and control group vary among studies [131], but there was no statistically significant difference of serum apelin levels between SSc patients and control group [7, 131]. In the context of the still unclear role of apelin, further researches are required to establish its position in SSc pathogenesis.

Omentin is a newly identified adipokine that is produced abundantly by visceral adipose tissue. It was reported that omentin has anti-inflammatory properties acting via AMPK signaling pathway and has a potent vasodilatory effect by activating endothelial nitric oxide synthase (eNOS). Omentin suppresses inflammatory responses in endothelial cells, inhibits chemoattraction and production of ECM [120]. So far, only one study has investigated omentin and its role in SSc pathogenesis and clinical outcome [83]. Serum concentration of omentin was comparable between SSc patients and healthy control. However, omentin level was decreased in dcSSc patients compared to lcSSc patients (715.4 vs. $980.2 \mathrm{ng} / \mathrm{mL}, p=0.013)$. What is more, omentin level in $\mathrm{dcSSc}$ patients was positively correlated with disease duration ( $\leq 5$ vs. $>5$ years, $p=0.035$ ). Increased right ventricular systolic pressure was observed in SSc patients with elevated omentin concentration indicating a possible role of omentin as a biomarker of vascular involvement leading to SScrelated PAH (SSc-PAH) [83].

CTRP-3 (C1q/TNF-related protein) is one of emerging adipokines, whose molecular structure and function resemble adiponectin. It was indicated that CTRP-3 exerts antiinflammatory and anti-fibrotic effects in fibroblasts. Reduced fibrotic activity caused by CTRP- 3 is a consequence of targeting connective tissue growth factor (CTGF) and collagen I expression as well as TGF- $\beta$ production [44]. In rat model, CTRP-3 ameliorated TGF- $\beta$-induced expression of CTGF, proliferation, migration and collagen synthesis of adventitial fibroblasts [67]. CTRP-3 demonstrates a beneficial effect on the cardiovascular system potentially ameliorating pathological vascular remodeling [104]. Although there were only a few reports indicating the role of CTRP-3 in fibrosis, current studies suggest CTRP-3, similarly to adiponectin [94] and adipsin [57], may tie together adipokines, fibrosis and complement system. The exact position of CTRP-3 still awaits to be discovered, as there is a lack of research concerning its role in SSc pathogenesis (Table 2).

\section{Conclusions}

Adipose tissue is associated with SSc both in anatomic and functional manner. Although adipokines have been profoundly studied in many disorders, such as diabetes, metabolic syndrome and psoriasis, further investigations are required to establish their link with SSc. Adipokines may be linked with the course of SSc and its possible complications. Moreover, adipokines seem to influence the TLRs and PPARs signaling and expression. This suggests a pivotal role of both receptors in SSc pathogenesis. This review gives an insight into the complex role of adipokines in SSs which are involved in many processes such as immunomodulation and fibrosis. Adipokines are a heterogenic group of molecules; leptin, resistin and chemerin present a potential for triggering inflammation, while adiponectin, visfatin and vaspin exhibit mostly contradictory anti-inflammatory features. Novel adipokines such as adipsin, apelin, omentin and CTRP-3 appear also as molecules involved in SSc pathogenesis. In the future, adipokines may be useful as predictive and diagnostic factors in SSc. However, further researches are vital to establish the firm correlation between adipokines and SSc.

Funding There is no funding source.

\section{Compliance with ethical standards}

Conflict of interest The authors declare that they have no conflict of interest.

Ethical approval This article does not contain any studies with human participants or animals performed by any of the authors.

OpenAccess This article is distributed under the terms of the Creative Commons Attribution 4.0 International License (http://creativeco mmons.org/licenses/by/4.0/), which permits unrestricted use, distribution, and reproduction in any medium, provided you give appropriate credit to the original author(s) and the source, provide a link to the Creative Commons license, and indicate if changes were made.

\section{References}

1. Aborehab NM, El Bishbishy MH, Waly NE (2016) Resistin mediates tomato and broccoli extract effects on glucose homeostasis 
in high fat diet-induced obesity in rats. BMC Complement Altern Med 16:225. https://doi.org/10.1186/s12906-016-1203-0

2. Acedo SC, Gambero S, Cunha FG, Lorand-Metze I, Gambero A (2013) Participation of leptin in the determination of the macrophage phenotype: an additional role in adipocyte and macrophage crosstalk. In Vitro Cell Dev Biol Anim 49:473-478. https://doi.org/10.1007/s11626-013-9629-x

3. Ah Kioon MD, Tripodo C, Fernandez D, Kirou KA, Spiera RF, Crow MK, Gordon JK, Barrat FJ (2018) Plasmacytoid dendritic cells promote systemic sclerosis with a key role for TLR8. Sci Transl Med. https://doi.org/10.1126/scitranslmed.aam8458

4. Ahima RS, Scolaro LM, Park H-K (2016) Adipokines and metabolism. Metab Syndr. https://doi.org/10.1007/978-3-319-11251 $-0 \_24$

5. Akamata K, Asano Y, Taniguchi T, Yamashita T, Saigusa R, Nakamura K, Noda S, Aozasa N, Toyama T, Takahashi T, Ichimura Y, Sumida H, Tada Y, Sugaya M, Kadono T, Sato S (2015) Increased expression of chemerin in endothelial cells due to Fli1 deficiency may contribute to the development of digital ulcers in systemic sclerosis. Rheumatology 54:1308-1316. https ://doi.org/10.1093/rheumatology/keu479

6. Albanesi C, Scarponi C, Pallotta S, Daniele R, Bosisio D, Madonna S, Fortugno P, Gonzalvo-Feo S, Franssen JD, Parmentier M, De Pita O, Girolomoni G, Sozzani S (2009) Chemerin expression marks early psoriatic skin lesions and correlates with plasmacytoid dendritic cell recruitment. J Exp Med 206:249258. https://doi.org/10.1084/jem.20080129

7. Aozasa N, Asano Y, Akamata K, Noda S, Masui Y, Yamada D, Tamaki Z, Tada Y, Sugaya M, Kadono T, Sato S (2013) Serum apelin levels: clinical association with vascular involvements in patients with systemic sclerosis. J Eur Acad Dermatol Venereol 27:37-42. https://doi.org/10.1111/j.1468-3083.2011.04354.x

8. Arakawa H, Jinnin M, Muchemwa FC, Makino T, Kajihara I, Makino K, Honda N, Sakai K, Fukushima S, Ihn H (2011) Adiponectin expression is decreased in the involved skin and sera of diffuse cutaneous scleroderma patients. Exp Dermatol 20:764-766. https://doi.org/10.1111/j.1600-0625.2011.01310.x

9. Avouac J, Konstantinova I, Guignabert C, Pezet S, Sadoine J, Guilbert T, Cauvet A, Tu L, Luccarini JM, Junien JL, Broqua $\mathrm{P}$, Allanore Y (2017) Pan-PPAR agonist IVA337 is effective in experimental lung fibrosis and pulmonary hypertension. Ann Rheum Dis 76:1931-1940. https://doi.org/10.1136/annrheumdi s-2016-210821

10. Axelsson J, Bergsten A, Qureshi AR, Heimburger O, Barany P, Lonnqvist F, Lindholm B, Nordfors L, Alvestrand A, Stenvinkel $P$ (2006) Elevated resistin levels in chronic kidney disease are associated with decreased glomerular filtration rate and inflammation, but not with insulin resistance. Kidney Int 69:596-604. https://doi.org/10.1038/sj.ki.5000089

11. Banas M, Zabieglo K, Kasetty G, Kapinska-Mrowiecka M, Borowczyk J, Drukala J, Murzyn K, Zabel BA, Butcher EC, Schroeder JM, Schmidtchen A, Cichy J (2013) Chemerin is an antimicrobial agent in human epidermis. PLoS One 8:e58709. https://doi.org/10.1371/journal.pone.0058709

12. Benomar Y, Gertler A, De Lacy P, Crepin D, Ould Hamouda H, Riffault L, Taouis M (2013) Central resistin overexposure induces insulin resistance through Toll-like receptor 4. Diabetes 62:102-114. https://doi.org/10.2337/db12-0237

13. Bhattacharyya S, Wang W, Qin W, Cheng K, Coulup S, Chavez S, Jiang S, Raparia K, De Almeida LMV, Stehlik C, Tamaki Z, Yin H, Varga J (2018) TLR4-dependent fibroblast activation drives persistent organ fibrosis in skin and lung. JCI Insight 3. https://doi.org/10.1172/jci.insight.98850

14. Bokarewa M, Nagaev I, Dahlberg L, Smith U, Tarkowski A (2005) Resistin, an adipokine with potent proinflammatory properties. J Immunol 174:5789-5795. https://doi.org/10.4049/ jimmunol.174.9.5789

15. Budulgan M, Dilek B, Dag SB, Batmaz I, Yildiz I, Sariyildiz MA, Cevik R, Nas K (2014) Relationship between serum leptin level and disease activity in patients with systemic sclerosis. Clin Rheumatol 33:335-339. https://doi.org/10.1007/s1006 7-013-2459-0

16. Cabrero À, Cubero M, Llaverías G, Alegret M, Sánchez R, Laguna JC, Vázquez-Carrera M (2005) Leptin down-regulates peroxisome proliferator-activated receptor $\gamma(\operatorname{PPAR} \gamma) \mathrm{mRNA}$ levels in primary human monocyte-derived macrophages. Mol Cell Biochem 275:173-179. https://doi.org/10.1007/s1101 0-005-1353-8

17. Chen B, Lyu Q, Zhang M, Zhang M, Liu W, Zhu S (2015) Leptin induces human lung fibroblast to trans-differentiate into myofibroblast. Xi bao yu fen zi mian yi xue za zhi Chin J Cell Mol Immunol 31:199-202

18. Chung WS, Lin CL, Sung FC, Hsu WH, Yang WT, Lu CC, Kao CH (2014) Systemic sclerosis increases the risks of deep vein thrombosis and pulmonary thromboembolism: a nationwide cohort study. Rheumatology 53:1639-1645. https://doi. org/10.1093/rheumatology/keu133

19. Ciechomska M, Cant R, Finnigan J, van Laar JM, O'Reilly S (2013) Role of toll-like receptors in systemic sclerosis. Expert Rev Mol Med 15:e9. https://doi.org/10.1017/erm.2013.10

20. Curat CA, Miranville A, Sengenes C, Diehl M, Tonus C, Busse R, Bouloumie A (2004) From blood monocytes to adipose tissueresident macrophages: induction of diapedesis by human mature adipocytes. Diabetes 53:1285-1292. https://doi.org/10.2337/ diabetes.53.5.1285

21. Daya M, Loilome W, Techasen A, Thanee M, Sa-Ngiamwibool P, Titapun A, Yongvanit P, Namwat N (2018) Progranulin modulates cholangiocarcinoma cell proliferation, apoptosis, and motility via the PI3K/pAkt pathway. Onco Targets Ther 11:395-408. https://doi.org/10.2147/OTT.S155511

22. De Rosa V, Procaccini C, Cali G, Pirozzi G, Fontana S, Zappacosta S, La Cava A, Matarese G (2007) A key role of leptin in the control of regulatory $\mathrm{T}$ cell proliferation. Immunity $26: 241-255$. https://doi.org/10.1016/j.immuni.2007.01.011

23. Devresse A, Aydin S, Le Quintrec M, Demoulin N, Stordeur P, Lambert C, Gastoldi S, Pirson Y, Jadoul M, Morelle J (2016) Complement activation and effect of eculizumab in scleroderma renal crisis. Medicine 95:e4459. https://doi.org/10.1097/ MD.0000000000004459. (Baltimore)

24. Dib LH, Ortega MT, Melgarejo T, Chapes SK (2016) Establishment and characterization of DB-1: a leptin receptor-deficient murine macrophage cell line. Cytotechnology 68:921-933. https ://doi.org/10.1007/s10616-015-9843-3

25. Eisinger K, Bauer S, Schaffler A, Walter R, Neumann E, Buechler C, Muller-Ladner U, Frommer KW (2012) Chemerin induces CCL2 and TLR4 in synovial fibroblasts of patients with rheumatoid arthritis and osteoarthritis. Exp Mol Pathol 92:90-96. https ://doi.org/10.1016/j.yexmp.2011.10.006

26. Fang F, Liu L, Yang Y, Tamaki Z, Wei J, Marangoni RG, Bhattacharyya S, Summer RS, Ye B, Varga J (2012) The adipokine adiponectin has potent anti-fibrotic effects mediated via adenosine monophosphate-activated protein kinase: novel target for fibrosis therapy. Arthritis Res Ther 14:R229. https://doi. org/10.1186/ar4070

27. Farina G, York M, Collins C, Lafyatis R (2011) dsRNA activation of endothelin-1 and markers of vascular activation in endothelial cells and fibroblasts. Ann Rheum Dis 70:544-550. https://doi.org/10.1136/ard.2010.132464 
28. Filkova M, Senolt L, Vencovsky J (2013) The role of resistin in inflammatory myopathies. Curr Rheumatol Rep 15:336. https:// doi.org/10.1007/s11926-013-0336-0

29. Fleischmajer R (1972) Alteration of subcutaneous tissue in systemic scleroderma. Arch Dermatol 105. https://doi.org/10.1001/ archderm.1972.01620040031005

30. Freitas Lima LC, Braga VA, do Socorro de Franca Silva M, Cruz JC, Sousa Santos SH, de Oliveira Monteiro MM, Balarini CM (2015) Adipokines, diabetes and atherosclerosis: an inflammatory association. Front Physiol 6:304. https://doi.org/10.3389/ fphys.2015.00304

31. Frey O, Herenius MMJ, Oliveira ASF, Wijbrandts CA, Gerlag DM, Tak PP, Lebre MC (2013) Anti-TNF therapy reduces serum levels of chemerin in rheumatoid arthritis: a new mechanism by which anti-TNF might reduce inflammation. PLoS One. https:// doi.org/10.1371/journal.pone.0057802

32. Fruhbeck G, Catalan V, Rodriguez A, Ramirez B, Becerril S, Salvador J, Portincasa P, Colina I, Gomez-Ambrosi J (2017) Involvement of the leptin-adiponectin axis in inflammation and oxidative stress in the metabolic syndrome. Sci Rep 7:6619. https ://doi.org/10.1038/s41598-017-06997-0

33. Galic S, Oakhill JS, Steinberg GR (2010) Adipose tissue as an endocrine organ. Mol Cell Endocrinol 316:129-139. https://doi. org/10.1016/j.mce.2009.08.018

34. Ghigliotti G, Barisione C, Garibaldi S, Fabbi P, Brunelli C, Spallarossa P, Altieri P, Rosa G, Spinella G, Palombo D, Arsenescu R, Arsenescu V (2014) Adipose tissue immune response: novel triggers and consequences for chronic inflammatory conditions. Inflammation 37:1337-1353. https://doi.org/10.1007/s1075 3-014-9914-1

35. Gonzalez M, Lind L, Soderberg S (2013) Leptin and endothelial function in the elderly: the prospective investigation of the vasculature in uppsala seniors (PIVUS) study. Atherosclerosis 228:485-490. https://doi.org/10.1016/j.atherosclerosis .2013 .03 .018

36. Gui X, Chen H, Cai H, Sun L, Gu L (2018) Leptin promotes pulmonary fibrosis development by inhibiting autophagy via PI3K/Akt/mTOR pathway. Biochem Biophys Res Commun 498:660-666. https://doi.org/10.1016/j.bbrc.2018.03.039

37. Ha YJ, Kang EJ, Song JS, Park YB, Lee SK, Choi ST (2014) Plasma chemerin levels in rheumatoid arthritis are correlated with disease activity rather than obesity. Jt Bone Spine 81:189190. https://doi.org/10.1016/j.jbspin.2013.07.013

38. Handjieva-Darlenska T, Boyadjieva N (2009) The effect of highfat diet on plasma ghrelin and leptin levels in rats. J Physiol Biochem 65:157-164. https://doi.org/10.1007/bf03179066

39. Haugen F, Drevon CA (2007) Activation of nuclear factor-kappaB by high molecular weight and globular adiponectin. Endocrinology 148:5478-5486. https://doi.org/10.1210/en.2007-0370

40. He Y, Lu L, Wei X, Jin D, Qian T, Yu A, Sun J, Cui J, Yang $\mathrm{Z}$ (2016) The multimerization and secretion of adiponectin are regulated by TNF-alpha. Endocrine 51:456-468. https://doi. org/10.1007/s12020-015-0741-4

41. Heiker JT (2014) Vaspin (serpinA12) in obesity, insulin resistance, and inflammation. J Pept Sci 20:299-306. https://doi. org/10.1002/psc. 2621

42. Hida K, Wada J, Eguchi J, Zhang H, Baba M, Seida A, Hashimoto I, Okada T, Yasuhara A, Nakatsuka A, Shikata K, Hourai S, Futami J, Watanabe E, Matsuki Y, Hiramatsu R, Akagi S, Makino H, Kanwar YS (2005) Visceral adipose tissue-derived serine protease inhibitor: a unique insulin-sensitizing adipocytokine in obesity. Proc Natl Acad Sci USA 102:10610-10615. https://doi.org/10.1073/pnas.0504703102

43. Ho YY, Lagares D, Tager AM, Kapoor M (2014) Fibrosis-a lethal component of systemic sclerosis. Nat Rev Rheumatol 10:390-402. https://doi.org/10.1038/nrrheum.2014.53
44. Hofmann C, Chen N, Obermeier F, Paul G, Buchler C, Kopp A, Falk W, Schaffler A (2011) C1q/TNF-related protein-3 (CTRP-3) is secreted by visceral adipose tissue and exerts antiinflammatory and antifibrotic effects in primary human colonic fibroblasts. Inflamm Bowel Dis 17:2462-2471. https://doi.org/10.1002/ ibd. 21647

45. Huang S, Chen L, Lu L, Li L (2016) The apelin-APJ axis: a novel potential therapeutic target for organ fibrosis. Clin Chim Acta 456:81-88. https://doi.org/10.1016/j.cca.2016.02.025

46. Huertas A, Tu L, Gambaryan N, Girerd B, Perros F, Montani D, Fabre D, Fadel E, Eddahibi S, Cohen-Kaminsky S, Guignabert C, Humbert M (2012) Leptin and regulatory T-lymphocytes in idiopathic pulmonary arterial hypertension. Eur Respir J 40:895904. https://doi.org/10.1183/09031936.00159911

47. Hwang MS, Yu N, Stinson SY, Yue P, Newman RJ, Allan BB, Dornan D (2013) miR-221/222 targets adiponectin receptor 1 to promote the epithelial-to-mesenchymal transition in breast cancer. PLoS One 8:e66502. https://doi.org/10.1371/journ al.pone.0066502

48. Jaedicke KM, Roythorne A, Padget K, Todryk S, Preshaw PM, Taylor JJ (2013) Leptin up-regulates TLR2 in human monocytes. J Leukoc Biol 93:561-571. https://doi.org/10.1189/jlb.1211606

49. Jung MY, Kim HS, Hong HJ, Youn BS, Kim TS (2012) Adiponectin induces dendritic cell activation via PLCgamma/JNK/ NF-kappaB pathways, leading to Th1 and Th17 polarization. J Immunol 188:2592-2601. https://doi.org/10.4049/jimmu nol.1102588

50. Kang SW, Kim MS, Kim HS, Kim Y, Shin D, Park JH, Kang YH (2013) Celastrol attenuates adipokine resistin-associated matrix interaction and migration of vascular smooth muscle cells. J Cell Biochem 114:398-408. https://doi.org/10.1002/jcb.24374

51. Kanzler SA, Januario AC, Paschoalini MA (2011) Involvement of $\beta 3$-adrenergic receptors in the control of food intake in rats. Braz J Med Biol Res 44:1141-1147. https://doi.org/10.1590/ s0100-879x2011007500127

52. Karrasch T, Schaeffler A (2016) Adipokines and the role of visceral adipose tissue in inflammatory bowel disease. Ann Gastroenterol 29:424-438. https://doi.org/10.20524/aog.2016.0077

53. Kershaw EE, Flier JS (2004) Adipose tissue as an endocrine organ. J Clin Endocrinol Metab 89:2548-2556. https://doi. org/10.1210/jc.2004-0395

54. Kim EK, Kwon JE, Lee SY, Lee EJ, Kim DS, Moon SJ, Lee J, Kwok SK, Park SH, Cho ML (2017) IL-17-mediated mitochondrial dysfunction impairs apoptosis in rheumatoid arthritis synovial fibroblasts through activation of autophagy. Cell Death Dis 8:e2565. https://doi.org/10.1038/cddis.2016.490

55. Knobler R, Moinzadeh P, Hunzelmann N, Kreuter A, Cozzio A, Mouthon L, Cutolo M, Rongioletti F, Denton CP, Rudnicka L, Frasin LA, Smith V, Gabrielli A, Aberer E, Bagot M, Bali G, Bouaziz J, Braae Olesen A, Foeldvari I, Frances C, Jalili A, Just U, Kahari V, Karpati S, Kofoed K, Krasowska D, Olszewska M, Orteu C, Panelius J, Parodi A, Petit A, Quaglino P, Ranki A, Sanchez Schmidt JM, Seneschal J, Skrok A, Sticherling M, Sunderkotter C, Taieb A, Tanew A, Wolf P, Worm M, Wutte NJ, Krieg T (2017) European dermatology forum S1-guideline on the diagnosis and treatment of sclerosing diseases of the skin, Part 1: localized scleroderma, systemic sclerosis and overlap syndromes. J Eur Acad Dermatol Venereol 31:1401-1424. https ://doi.org/10.1111/jdv.14458

56. Knobler R, Moinzadeh P, Hunzelmann N, Kreuter A, Cozzio A, Mouthon L, Cutolo M, Rongioletti F, Denton CP, Rudnicka L, Frasin LA, Smith V, Gabrielli A, Aberer E, Bagot M, Bali G, Bouaziz J, Braae Olesen A, Foeldvari I, Frances C, Jalili A, Just U, Kahari V, Karpati S, Kofoed K, Krasowska D, Olszewska M, Orteu C, Panelius J, Parodi A, Petit A, Quaglino P, Ranki A, Sanchez Schmidt JM, Seneschal J, Skrok A, Sticherling M, 
Sunderkotter C, Taieb A, Tanew A, Wolf P, Worm M, Wutte NJ, Krieg T (2017) European dermatology forum S1-guideline on the diagnosis and treatment of sclerosing diseases of the skin, Part 2: Scleromyxedema, scleredema and nephrogenic systemic fibrosis. J Eur Acad Dermatol Venereol 31:1581-1594. https:// doi.org/10.1111/jdv. 14466

57. Korman BD, Marangoni RG, Hinchcliff M, Shah SJ, Carns M, Hoffmann A, Ramsey-Goldman R, Varga J (2017) Brief report: association of elevated adipsin levels with pulmonary arterial hypertension in systemic sclerosis. Arthritis Rheumatol 69:2062-2068. https://doi.org/10.1002/art.40193

58. Krasowska D, Rudnicka L, Dańczak-Pazdrowska A, Chodorowska G, Woźniacka A, Lis-Święty A, Czuwara J, Maj J, Majewski S, Sysa-Jędrzejowska A, Wojas-Pelc A (2017) Systemic sclerosis-diagnostic and therapeutic recommendations of the Polish Dermatological Society. Part 1: diagnosis and monitoring. Dermatol Rev Przegląd Dermatologiczny 104:483-498. https://doi.org/10.5114/dr.2017.71214

59. Lakota K, Wei J, Carns M, Hinchcliff M, Lee J, Whitfield ML, Sodin-Semrl S, Varga J (2012) Levels of adiponectin, a marker for PPAR-gamma activity, correlate with skin fibrosis in systemic sclerosis: potential utility as biomarker? Arthritis Res Ther 14:R102. https://doi.org/10.1186/ar3827

60. Lamichane S, Dahal Lamichane B, Kwon SM (2018) Pivotal roles of peroxisome proliferator-activated receptors (PPARs) and their signal cascade for cellular and whole-body energy homeostasis. Int J Mol Sci 19. https://doi.org/10.3390/ijms1 9040949

61. Lee M, Lee E, Jin SH, Ahn S, Kim SO, Kim J, Choi D, Lim KM, Lee ST, Noh M (2018) Leptin regulates the pro-inflammatory response in human epidermal keratinocytes. Arch Dermatol Res 310:351-362. https://doi.org/10.1007/s00403-018-1821-0

62. Lee SE, Kim H-S (2012) Human resistin in cardiovascular disease. J Smooth Muscle Res 48:27-35. https://doi.org/10.1540/ jsmr.48.27

63. Lee YH, Song GG (2017) Meta-analysis of circulating adiponectin, leptin, and resistin levels in systemic sclerosis. Z Rheumatol 76:789-797. https://doi.org/10.1007/s00393-016-0172-5

64. Lei L, Zhong XN, He ZY, Zhao C, Sun XJ (2015) IL-21 induction of CD4 $+\mathrm{T}$ cell differentiation into Th17 cells contributes to bleomycin-induced fibrosis in mice. Cell Biol Int 39:388-399. https://doi.org/10.1002/cbin.10410

65. Leonardini A, Laviola L, Perrini S, Natalicchio A, Giorgino F (2009) Cross-talk between PPARgamma and insulin signaling and modulation of insulin sensitivity. PPAR Res 2009:818945. https://doi.org/10.1155/2009/818945

66. Li P, Yang L, Ma CL, Liu B, Zhang X, Ding R, Bi LQ (2015) Low-molecular-weight adiponectin is more closely associated with disease activity of rheumatoid arthritis than other adiponectin multimeric forms. Clin Rheumatol 34:1025-1030. https://doi. org/10.1007/s10067-015-2899-9

67. Lin S, Ma S, Lu P, Cai W, Chen Y, Sheng J (2014) Effect of CTRP3 on activation of adventitial fibroblasts induced by TGFbeta1 from rat aorta in vitro. Int J Clin Exp Pathol 7:2199-2208

68. Lin Y, Yang X, Yue W, Xu X, Li B, Zou L, He R (2014) Chemerin aggravates DSS-induced colitis by suppressing M2 macrophage polarization. Cell Mol Immunol 11:355-366. https ://doi.org/10.1038/cmi.2014.15

69. Liu S, Dong Y, Wang T, Zhao S, Yang K, Chen X, Zheng C (2014) Vaspin inhibited proinflammatory cytokine induced activation of nuclear factor-kappa B and its downstream molecules in human endothelial EA.hy926 cells. Diabetes Res Clin Pract 103:482-488. https://doi.org/10.1016/j.diabres.2013.12.002

70. Lourenco EV, Liu A, Matarese G, La Cava A (2016) Leptin promotes systemic lupus erythematosus by increasing autoantibody production and inhibiting immune regulation. Proc Natl Acad
Sci USA 113:10637-10642. https://doi.org/10.1073/pnas.16071 01113

71. Lv D, Li H, Chen L (2013) Apelin and APJ, a novel critical factor and therapeutic target for atherosclerosis. Acta Biochim Biophys Sin 45:527-533. https://doi.org/10.1093/abbs/gmt040. (Shanghai)

72. Malli F, Georgoulias P (2015) Leptin and adiponectin levels in idiopathic pulmonary fibrosis: association with hypoxia. J Obes Weight Loss Ther. https://doi.org/10.4172/2165-7904.1000284

73. Mandal P, Pratt BT, Barnes M, McMullen MR, Nagy LE (2011) Molecular mechanism for adiponectin-dependent M2 macrophage polarization: link between the metabolic and innate immune activity of full-length adiponectin. J Biol Chem 286:13460-13469. https://doi.org/10.1074/jbc.M110.204644

74. Marangoni RG, Korman BD, Wei J, Wood TA, Graham LV, Whitfield ML, Scherer PE, Tourtellotte WG, Varga J (2015) Myofibroblasts in murine cutaneous fibrosis originate from adiponectin-positive intradermal progenitors. Arthritis Rheumatol 67:1062-1073. https://doi.org/10.1002/art.38990

75. Marangoni RG, Masui Y, Fang F, Korman B, Lord G, Lee J, Lakota K, Wei J, Scherer PE, Otvos L, Yamauchi T, Kubota N, Kadowaki T, Asano Y, Sato S, Tourtellotte WG, Varga J (2017) Adiponectin is an endogenous anti-fibrotic mediator and therapeutic target. Sci Rep 7:4397. https://doi.org/10.1038/s4159 8-017-04162-1

76. Mariani F, Roncucci L (2015) Chemerin/chemR23 axis in inflammation onset and resolution. Inflamm Res 64:85-95. https://doi. org/10.1007/s00011-014-0792-7

77. Martin-Romero C, Santos-Alvarez J, Goberna R, SanchezMargalet V (2000) Human leptin enhances activation and proliferation of human circulating T lymphocytes. Cell Immunol 199:15-24. https://doi.org/10.1006/cimm.1999.1594

78. Martinez FO, Gordon S (2014) The M1 and M2 paradigm of macrophage activation: time for reassessment. F1000 Prime Rep 6:13. https://doi.org/10.12703/P6-13

79. Masui Y, Asano Y, Akamata K, Aozasa N, Noda S, Taniguchi T, Takahashi T, Ichimura Y, Toyama T, Sumida H, Kuwano Y, Yanaba K, Tada Y, Sugaya M, Sato S, Kadono T (2014) Serum resistin levels: a possible correlation with pulmonary vascular involvement in patients with systemic sclerosis. Rheumatol Int 34:1165-1170. https://doi.org/10.1007/s00296-013-2880-3

80. Masui Y, Asano Y, Shibata S, Noda S, Akamata K, Aozasa N, Taniguchi T, Takahashi T, Ichimura Y, Toyama T, Sumida H, Yanaba K, Tada Y, Sugaya M, Sato S, Kadono T (2013) A possible contribution of visfatin to the resolution of skin sclerosis in patients with diffuse cutaneous systemic sclerosis via a direct anti-fibrotic effect on dermal fibroblasts and Th1 polarization of the immune response. Rheumatology 52:1239-1244. https://doi. org/10.1093/rheumatology/ket010

81. Mattern A, Zellmann T, Beck-Sickinger AG (2014) Processing, signaling, and physiological function of chemerin. IUBMB Life 66:19-26. https://doi.org/10.1002/iub.1242

82. Mayi TH, Duhem C, Copin C, Bouhlel MA, Rigamonti E, Pattou F, Staels B, Chinetti-Gbaguidi G (2010) Visfatin is induced by peroxisome proliferator-activated receptor gamma in human macrophages. FEBS J 277:3308-3320. https://doi.org/10.111 1/j.1742-4658.2010.07729.x

83. Miura S, Asano Y, Saigusa R, Yamashita T, Taniguchi T, Takahashi T, Ichimura Y, Toyama T, Tamaki Z, Tada Y, Sugaya M, Sato S, Kadono T (2015) Serum omentin levels: a possible contribution to vascular involvement in patients with systemic sclerosis. J Dermatol 42:461-466. https://doi. org/10.1111/1346-8138.12824

84. Miura S, Asano Y, Saigusa R, Yamashita T, Taniguchi $\mathrm{T}$, Takahashi T, Ichimura Y, Toyama T, Tamaki Z, Tada Y, Sugaya M, Sato S, Kadono T (2015) Serum vaspin 
levels: a possible correlation with digital ulcers in patients with systemic sclerosis. J Dermatol 42:528-531. https://doi. org/10.1111/1346-8138.12810

85. Neumeier M, Weigert J, Schaffler A, Wehrwein G, Muller-Ladner U, Scholmerich J, Wrede C, Buechler C (2006) Different effects of adiponectin isoforms in human monocytic cells. J Leukoc Biol 79:803-808. https://doi.org/10.1189/jlb.0905521

86. Nikitorowicz-Buniak J, Denton CP, Abraham D, Stratton R (2015) Partially evoked epithelial-mesenchymal transition (EMT) is associated with increased tgfbeta signaling within lesional scleroderma skin. PLoS One 10:e0134092. https://doi. org/10.1371/journal.pone.0134092

87. Ohashi K, Parker JL, Ouchi N, Higuchi A, Vita JA, Gokce N, Pedersen AA, Kalthoff C, Tullin S, Sams A, Summer R, Walsh K (2010) Adiponectin promotes macrophage polarization toward an anti-inflammatory phenotype. J Biol Chem 285:6153-6160. https://doi.org/10.1074/jbc.M109.088708

88. Ohyoshi Y, Makino T, Jinnin M, Nakayama W, Fukushima S, Inoue Y, Ihn H (2013) Serum levels of leptin receptor in patients with systemic sclerosis. Intractable Rare Dis Res 2:55-58. https://doi.org/10.5582/irdr.2013.v2.2.55

89. Olewicz-Gawlik A, Danczak-Pazdrowska A, Kuznar-Kaminska B, Batura-Gabryel H, Katulska K, Wojciech S, Trzybulska D, Hrycaj P (2015) Circulating adipokines and organ involvement in patients with systemic sclerosis. Acta Reumatol Port 40:156-162

90. Osborne LC, Joyce KL, Alenghat T, Sonnenberg GF, Giacomin PR, Du Y, Bergstrom KS, Vallance BA, Nair MG (2013) Resistin-like molecule alpha promotes pathogenic Th17 cell responses and bacterial-induced intestinal inflammation. $\mathbf{J}$ Immunol 190:2292-2300. https://doi.org/10.4049/jimmu nol.1200706

91. Ozgen M, Koca SS, Aksoy K, Dagli N, Ustundag B, Isik A (2011) Visfatin levels and intima-media thicknesses in rheumatic diseases. Clin Rheumatol 30:757-763. https://doi.org/10.1007/ s10067-010-1649-2

92. Ozgen M, Koca SS, Isik B, Gundogdu B, Ustundag B, Isik A (2011) Serum adiponectin and vaspin levels in systemic sclerosis. Turk J Biochem 36:35-42

93. Patel L, Buckels AC, Kinghorn IJ, Murdock PR, Holbrook JD, Plumpton C, Macphee CH, Smith SA (2003) Resistin is expressed in human macrophages and directly regulated by PPAR $\gamma$ activators. Biochem Biophys Res Commun 300:472-476. https://doi.org/10.1016/s0006-291x(02)02841-3

94. Peake PW, Shen Y, Walther A, Charlesworth JA (2008) Adiponectin binds C1q and activates the classical pathway of complement. Biochem Biophys Res Commun 367:560-565. https:// doi.org/10.1016/j.bbrc.2007.12.161

95. Pehlivan Y, Onat AM, Ceylan N, Turkbeyler IH, Buyukhatipoglu H, Comez G, Babacan T, Tarakcioglu M (2012) Serum leptin, resistin and TNF-alpha levels in patients with systemic sclerosis: the role of adipokines in scleroderma. Int J Rheum Dis 15:374379. https://doi.org/10.1111/j.1756-185X.2012.01755.x

96. Poeggeler B, Schulz C, Pappolla MA, Bodo E, Tiede S, Lehnert H, Paus R (2010) Leptin and the skin: a new frontier. Exp Dermatol 19:12-18. https://doi.org/10.1111/j.1600-0625.2009.00930 .x

97. Qi Q, Wang J, Li H, Yu Z, Ye X, Hu FB, Franco OH, Pan A, Liu Y, Lin X (2008) Associations of resistin with inflammatory and fibrinolytic markers, insulin resistance, and metabolic syndrome in middle-aged and older Chinese. Eur J Endocrinol 159:585593. https://doi.org/10.1530/EJE-08-0427

98. Qiu W, Chen N, Zhang Q, Zhuo L, Wang X, Wang D, Jin H (2014) Resistin increases platelet P-selectin levels via p38 MAPK signal pathway. Diabetes Vasc Dis Res 11:121-124. https ://doi.org/10.1177/1479164113513912
99. Rajkumar VS, Howell K, Csiszar K, Denton CP, Black CM, Abraham DJ (2005) Shared expression of phenotypic markers in systemic sclerosis indicates a convergence of pericytes and fibroblasts to a myofibroblast lineage in fibrosis. Arthritis Res Ther 7:R1113-R1123. https://doi.org/10.1186/ar1790

100. Reis BS, Lee K, Fanok MH, Mascaraque C, Amoury M, Cohn LB, Rogoz A, Dallner OS, Moraes-Vieira PM, Domingos AI, Mucida D (2015) Leptin receptor signaling in T cells is required for Th17 differentiation. J Immunol 194:5253-5260. https://doi. org/10.4049/jimmunol.1402996

101. Rivera-Gonzalez G, Shook B, Horsley V (2014) Adipocytes in skin health and disease. Cold Spring Harb Perspect Med. https ://doi.org/10.1101/cshperspect.a015271

102. Rosenbaum M, Nicolson M, Hirsch J, Heymsfield SB, Gallagher D, Chu F, Leibel RL (1996) Effects of gender, body composition, and menopause on plasma concentrations of leptin. J Clin Endocrinol Metab 81:3424-3427. https://doi.org/10.1210/ jcem.81.9.8784109

103. Sahu A (2003) Leptin signaling in the hypothalamus: emphasis on energy homeostasis and leptin resistance. Front Neuroendocrinol 24:225-253. https://doi.org/10.1016/j.yfrne.2003.10.001

104. Sawicka M, Janowska J, Chudek J (2016) Potential beneficial effect of some adipokines positively correlated with the adipose tissue content on the cardiovascular system. Int J Cardiol 222:581-589. https://doi.org/10.1016/j.ijcard.2016.07.054

105. Scambi C, Ugolini S, Jokiranta TS, De Franceschi L, Bortolami O, La Verde V, Guarini P, Caramaschi P, Ravagnani V, Martignoni G, Colato C, Pedron S, Benedetti F, Sorio M, Poli F, Biasi D (2015) The local complement activation on vascular bed of patients with systemic sclerosis: a hypothesis-generating study. PLoS One 10:e0114856. https://doi.org/10.1371/journ al.pone. 0114856

106. Schober F, Neumeier M, Weigert J, Wurm S, Wanninger J, Schaffler A, Dada A, Liebisch G, Schmitz G, Aslanidis C, Buechler C (2007) Low molecular weight adiponectin negatively correlates with the waist circumference and monocytic IL- 6 release. Biochem Biophys Res Commun 361:968-973. https://doi. org/10.1016/j.bbrc.2007.07.106

107. Senaldi G, Lupoli S, Vergani D, Black CM (1989) Activation of the complement system in systemic sclerosis. Relationship to clinical severity. Arthritis Rheum 32:1262-1267. https://doi. org/10.1002/anr.1780321011

108. Shirakawa K, Yan X, Shinmura K, Endo J, Kataoka M, Katsumata $\mathrm{Y}$, Yamamoto T, Anzai A, Isobe S, Yoshida N, Itoh H, Manabe I, Sekai M, Hamazaki Y, Fukuda K, Minato N, Sano M (2016) Obesity accelerates T cell senescence in murine visceral adipose tissue. J Clin Invest 126:4626-4639. https://doi. org/10.1172/JCI88606

109. Siersbaek R, Nielsen R, Mandrup S (2010) PPARgamma in adipocyte differentiation and metabolism-novel insights from genome-wide studies. FEBS Lett 584:3242-3249. https://doi. org/10.1016/j.febslet.2010.06.010

110. Stofkova A (2010) Resistin and visfatin: regulators of insulin sensitivity, inflammation and immunity. Endocr Regul 44:25-36. https://doi.org/10.4149/endo_2010_01_25

111. Tan W, Wang L, Ma Q, Qi M, Lu N, Zhang L, Han B (2015) Adiponectin as a potential tumor suppressor inhibiting epithelialto-mesenchymal transition but frequently silenced in prostate cancer by promoter methylation. Prostate 75:1197-1205. https ://doi.org/10.1002/pros.23002

112. Tarkowski A, Bjersing J, Shestakov A, Bokarewa MI (2009) Resistin competes with lipopolysaccharide for binding to tolllike receptor 4. J Cell Mol Med 14:1419-1431. https://doi.org/1 0.1111/j.1582-4934.2009.00899.x

113. Timár O, Soltész P, Szamosi S, Dér H, Szántó S, Szekanecz Z, Szücs G (2008) Increased arterial stiffness as the marker 
of vascular involvement in systemic sclerosis. J Rheumatol 35:1329-1333

114. Truchetet ME, Brembilla NC, Montanari E, Lonati P, Raschi E, Zeni S, Fontao L, Meroni PL, Chizzolini C (2013) Interleukin-17A + cell counts are increased in systemic sclerosis skin and their number is inversely correlated with the extent of skin involvement. Arthritis Rheum 65:1347-1356. https://doi. org/10.1002/art.37860

115. Varga J, Trojanowska M, Kuwana M (2017) Pathogenesis of systemic sclerosis: recent insights of molecular and cellular mechanisms and therapeutic opportunities. J Scleroderma Relat Disord 2:137-152. https://doi.org/10.5301/jsrd.5000249

116. Verma S, Li SH, Wang CH, Fedak PW, Li RK, Weisel RD, Mickle DA (2003) Resistin promotes endothelial cell activation: further evidence of adipokine-endothelial interaction. Circulation 108:736-740. https://doi.org/10.1161/01.CIR.0000084503 .91330 .49

117. Vitseva OI, Tanriverdi K, Tchkonia TT, Kirkland JL, McDonnell ME, Apovian CM, Freedman J, Gokce N (2008) Inducible Toll-like receptor and NF-kappaB regulatory pathway expression in human adipose tissue. Obesity 16:932-937. https://doi. org/10.1038/oby.2008.25. (Silver Spring)

118. Waki H, Yamauchi T, Kamon J, Ito Y, Uchida S, Kita S, Hara K, Hada Y, Vasseur F, Froguel P, Kimura S, Nagai R, Kadowaki T (2003) Impaired multimerization of human adiponectin mutants associated with diabetes. Molecular structure and multimer formation of adiponectin. J Biol Chem 278:40352-40363. https:// doi.org/10.1074/jbc.M300365200

119. Waki H, Yamauchi T, Kamon J, Kita S, Ito Y, Hada Y, Uchida S, Tsuchida A, Takekawa S, Kadowaki T (2005) Generation of globular fragment of adiponectin by leukocyte elastase secreted by monocytic cell line THP-1. Endocrinology 146:790-796. https://doi.org/10.1210/en.2004-1096

120. Watanabe T, Watanabe-Kominato K, Takahashi Y, Kojima M, Watanabe R (2017) Adipose tissue-derived omentin-1 function and regulation. Compr Physiol 7:765-781. https://doi. org/10.1002/cphy.c160043

121. Wilson MS, Madala SK, Ramalingam TR, Gochuico BR, Rosas IO, Cheever AW, Wynn TA (2010) Bleomycin and IL-1betamediated pulmonary fibrosis is IL-17A dependent. J Exp Med 207:535-552. https://doi.org/10.1084/jem.20092121

122. Wu M, Melichian DS, Chang E, Warner-Blankenship M, Ghosh AK, Varga J (2009) Rosiglitazone abrogates bleomycin-induced scleroderma and blocks profibrotic responses through peroxisome proliferator-activated receptor-gamma. Am J Pathol 174:519-533. https://doi.org/10.2353/ajpath.2009.080574

123. Wynn TA (2004) Fibrotic disease and the $\mathrm{T}(\mathrm{H}) 1 / \mathrm{T}(\mathrm{H}) 2$ paradigm. Nat Rev Immunol 4:583-594. https://doi.org/10.1038/ nri1412

124. Xiao K, Zou WH, Yang Z, Rehman ZU, Ansari AR, Yuan HR, Zhou Y, Cui L, Peng KM, Song H (2015) The role of visfatin on the regulation of inflammation and apoptosis in the spleen of LPS-treated rats. Cell Tissue Res 359:605-618. https://doi. org/10.1007/s00441-014-1997-3

125. Xue B, Yu Y, Zhang Z, Guo F, Beltz TG, Thunhorst RL, Felder RB, Johnson AK (2016) Leptin mediates high-fat diet sensitization of angiotensin II-elicited hypertension by upregulating the brain renin-angiotensin system and inflammation. Hypertension 67:970-976. https://doi.org/10.1161/HYPERTENSIONAHA .115 .06736

126. Xue K, Liu H, Jian Q, Liu B, Zhu D, Zhang M, Gao L, Li C (2013) Leptin induces secretion of pro-inflammatory cytokines by human keratinocytes in vitro-a possible reason for increased severity of psoriasis in patients with a high body mass index. Exp Dermatol 22:406-410. https://doi.org/10.1111/exd.12162

127. Yamaguchi N, Argueta JG, Masuhiro Y, Kagishita M, Nonaka K, Saito T, Hanazawa S, Yamashita Y (2005) Adiponectin inhibits Toll-like receptor family-induced signaling. FEBS Lett 579:6821-6826. https://doi.org/10.1016/j.febslet.2005.11.019

128. Yang J, Zhang K, Song H, Wu M, Li J, Yong Z, Jiang S, Kuang $\mathrm{X}$, Zhang T (2016) Visfatin is involved in promotion of colorectal carcinoma malignancy through an inducing EMT mechanism. Oncotarget 7:32306-32317. https://doi.org/10.18632/oncotarget .8615

129. Yang X, Chen B, Liu T, Chen X (2014) Reversal of myofibroblast differentiation: a review. Eur J Pharmacol 734:83-90. https://doi. org/10.1016/j.ejphar.2014.04.007

130. Yang X, Yang J, Xing X, Wan L, Li M (2014) Increased frequency of Th17 cells in systemic sclerosis is related to disease activity and collagen overproduction. Arthritis Res Ther 16:R4. https://doi.org/10.1186/ar4430

131. Yokoyama Y, Sekiguchi A, Fujiwara C, Uchiyama A, Uehara A, Ogino S, Torii R, Ishikawa O, Motegi SI (2018) Inhibitory regulation of skin fibrosis in systemic sclerosis by apelin/APJ signaling. Arthritis Rheumatol 70:1661-1672. https://doi.org/10.1002/ art. 40533

132. Zhang F, Basinski MB, Beals JM, Briggs SL, Churgay LM, Clawson DK, DiMarchi RD, Furman TC, Hale JE, Hsiung HM, Schoner BE, Smith DP, Zhang XY, Wery JP, Schevitz RW (1997) Crystal structure of the obese protein leptin-E100. Nature 387:206-209. https://doi.org/10.1038/387206a0

133. Zhang K, Guo Y, Ge Z, Zhang Z, Da Y, Li W, Zhang Z, Xue Z, Li Y, Ren Y, Jia L, Chan KH, Yang F, Yan J, Yao Z, Xu A, Zhang R (2017) Adiponectin suppresses T helper 17 cell differentiation and limits autoimmune CNS inflammation via the SIRT1/PPARgamma/RORgammat pathway. Mol Neurobiol 54:4908-4920. https://doi.org/10.1007/s12035-016-0036-7

134. Zhang Y, Proenca R, Maffei M, Barone M, Leopold L, Friedman JM (1994) Positional cloning of the mouse obese gene and its human homologue. Nature 372:425-432. https://doi. org/10.1038/372425a0

135. Zvaifler NJ (2006) Relevance of the stroma and epithelial-mesenchymal transition (EMT) for the rheumatic diseases. Arthritis Res Ther 8:210. https://doi.org/10.1186/ar1963

136. Zylla S, Rettig R, Volzke H, Endlich K, Nauck M, Friedrich $N$ (2018) Serum chemerin levels are inversely associated with renal function in a general population. Clin Endocrinol (Oxf) 88:146-153. https://doi.org/10.1111/cen.13449

Publisher's Note Springer Nature remains neutral with regard to jurisdictional claims in published maps and institutional affiliations. 